\title{
Analisis Maintenance Productivity pada Mesin Steel VMI untuk Menghitung Overall Equipment Effectiveness
}

\author{
Danang Aditya Pradana1, Sukanta ${ }^{* 2}$, dan Rizki Achmad Darajatun ${ }^{3}$ \\ 1,2,3 Program Studi Teknik Industri, Fakultas Teknik, Universitas Singaperbangsa Karawang, \\ Jl. H. S. Ronggowaluyo Telukjambe Timur, Karwang, 41361, Indonesia

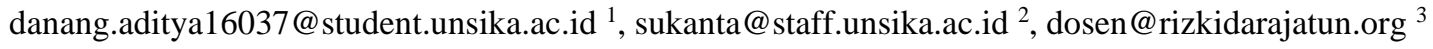

DOI: 10.20961/performa.19.2.43687

\begin{abstract}
Abstrak
Perusahaan yang bergerak dalam bidang produksi ban kendaraan. Dalam proses produksinya dilakukan penilaian tingkat efektifitas mesin, khususnya pada mesin Steel VMI yang dilakukan oleh Bagian Industrial Engineering. Adapun tujuan dalam penelitian ini untuk melakukan identifikasi penyebab masalah rendahnya nilai overall Equipment Effectivness (OEE) pada mesin Steel VMI tersebut. Dalam pengukuran nilai OEE pada mesin Steel VMI tersebut, maka dilakukan usulan perbaikan untuk meningkatkan rendahnya nilai OEE nya. Metode Penelitian untuk pemecahan masalah dengan menghitung dan menganalisis nilai availability, nilai performance dan nilai quality dan penentuan six big losses. Dari hasil penelitian bahwa mesin Steel VMI memiliki nilai availability 84\%, nilai performance $71 \%$, dan nilai quality 100\%, maka hasil perhitungan nilai OEE nya sebesar 59\%. Dengan nilai OEE tersebut masih rendah di bawah nilai standar OEE yaitu $85 \%$. Nilai rendahnya OEE tersebut bahwa disebabkan oleh losses terbesar dari equipment failure losses sebesar $41.49 \%$, reduce speed losses sebesar $41.05 \%$ dan chokotei/ idling minor stoppage yaitu sebesar 17,46\%. Penyebab rendahnya nilai OEE dan losses time disebebkan oleh schedule preventive maintenance terlalu lama, loss time pada proses perbaikan mesin kurang lengkap dan detil, dan Tidak tersedianya spare parts dan material terlalu besar pada mesin Steel VMI dan kurangnya pengawasan dan human error.
\end{abstract}

Kata kunci: Manajemen Pemeliharaan, TPM, OEE, Six Big Losses

\begin{abstract}
Companies engaged in the production of vehicle tires. In the production process, an assessment of the effectiveness of the machine is carried out, especially on the Steel VMI machine, which is carried out by the Industrial Engineering Department. The purpose of this research is to identify the cause of the problem with the low overall Equipment Effectiveness (OEE) value on the Steel VMI machine. In measuring the OEE value on the Steel VMI machine, suggestions are made to increase the low OEE value. Research methods for problem solving by calculating and analyzing the value of availability, value of performance and quality value and determination of six big losses. From the results of the research that the Steel VMI machine has a availability value of $84 \%$, a performance value of $71 \%$, and a quality value of $100 \%$, the result of the calculation of the OEE value is 59\%. With this OEE value is still low below the OEE standard value of $85 \%$. The low value of OEE is caused by the biggest losses from equipment failure losses of $41.49 \%$, reduced speed losses by $41.05 \%$ and chokotei / idling minor stoppage which is $17.46 \%$. The cause of low OEE value and loss time is due to too long preventive maintenance schedule, incomplete and detailed machine repair process loss time, and unavailability of spare parts and materials that are too large on Steel VMI machines and lack of supervision and human error.
\end{abstract}

Keywords: Maintenance Management, TPM, OEE, Six Big Losses

\section{Pendahuluan}

Perusahaan yang bergerak dalam bidang produksi ban kendaraa dalam menjalankan aktifitas produksinya, dilakukan penilaian tingkat efektifitas mesinnya terutama pada mesin Steel VMI yang dilakukan oleh Dept. Industrial Engineering. Perusahaan perlu memperhitungkan keuntungan dan kerugian kondisi riil. Salah satu kerugian dalam kegiatan produksi adalah kurangnya tingkat efektif dan efisien dari kegiatan produksi karena banyak hal seperti waste atau

${ }^{*}$ Corresponding author 
loss. Loss didalam proses produksi diantaranya adalah kerusakan mesin, idle time dari operator, dan masalah kualitas produk. Dengan demikian, bahwa dibutuhkan suatu pendekatan yang bisa membantu perusahaan dalam menilai tingkat efektifitas dan efisiensi mesin tersebut.

Manajemen Perawatan Industri adalah upaya pengaturan aktivitas untuk menjaga kontinuitas produksi, sehingga dapat menghasilkan produk yang berkualitas dan memiliki daya saing, melalui pemeliharaan fasilitas industri. (Ir. Kurniawan F, M.Si., RQP, 2013). Adapun pendekatan yang bisa dilakukan dengan menggunakan pengukuran Overall Equipment Effectiveness (OEE). OEE adalah salah satu tool dalam Total Productive Maintenance (TPM) yang digunakan untuk mengevaluasi efisiensi suatu mesin atau peralatan, yaitu untuk mengukur produktivitas dalam kegiatan produksinya.(Saiful et al., 2014). Dilakukannya upgrading terhadap suatu proses untuk meminimalisir masalah seperti proses produksi, perakitanas dan mengganti komponen-komponen serta memodifikasi bagian mesin dan peralatan produksi. Juga dilakukan penerapan Autonomous Maintenance untuk melakukan investigasi terhadap standar mesin dan peralatan (pelapisan, pembersihan, dan pelumasan) (Sukanta, Maulana, et al., 2019).

Menurut Triwardani, et al. (2012) bahwa perbaikan mesin dan fasilitas produksi yang dapat mempertimbangkan nilai Risk Priority Number (RPN) > 50, dengan permasalahan yang disebabkan oleh setup mesin oleh operator; diperlukan program pelatihan kepada operator pemahaman tentang spare-parts mesin dan fasilitas; operator yang bekerja pola shift pertama/awal harus menuliskan pesan informasi pada log book mengenai kerusakan yang terjadi dan cara mengatasinya; sebelum proses produksi dimulai (awal shift), operator harus melakukan pengecekan yang lebih teliti pada settingan belt; Operator harus melakukan pembersihan dan pelumasan secara berkala pada mesin dan fasilitas pada saat aktifitas autonomous maintenance. (Triwardani et al., 2012)

Menurut Puvanasvaran, et al. (2013) bahwa Integrasi waktu ke dalam OEE bahwa membuat produk pada waktu siklus yang konstan dengan rasio kinerja peralatan $100 \%$ dengan pendekatan tradisional sepanjang waktu siklus ideal. Selain itu, mengejar nilai OEE yang tinggi dapat menyebabkan terjadinya over produksi terutama pada periode permintaan rendah. (Puvanasvaran et al., 2013)

Berdasarkan kajian awal pada perusahaan bahwa untuk persentase untuk mesin Steel VMI sebesar 53\%, mesin Steel Fischer 1 sebesar 59\%, mesin Steel Fischer 2 sebesar 72\%, dan mesin Steel Fischer 3 sebesar 58\%. Dengan persentase tersebut masih terendah pada mesin Steel VMI dengan rata-rata 53\%. Dengan demikian, maka perlu dilakukan penelitian untuk menghitung nilai kinerja mesin dengan metode OEE. (S.Nakajima, 1988) dalam buku "Introduction to TPM" mengatakan bahwa untuk mencapai tingkat efektivitas mesin produksi yang baik, maka nilai $O E E$ yang harus dicapai minimal adalah $85 \%$. Tujuan penelitian ini untuk melakukan identifikasi penyebab masalah rendahnya $O E E$ pada mesin Steel VMI dan usulan tindakan perbaikannya.

\section{Metode Penelitian}

Kerangka konseptual dari penelitian ini merupakan kerangka berfikir secara sistematik. Kerangka berfikir ini akan sangat membantu dalam menyusun alur fikir yang mengarah kepada proses metodologi penelitian sampai penarikan kesimpulan. Metode pengukuran yang sederhana dan komprehensif, seperti yang direkomendasikan oleh De Ron dan Rooda (2005), telah diperkenalkan dengan menggunakan metode rata-rata tertimbang. Beberapa campuran produk dengan jumlah berbeda dicakup oleh unit agregat untuk memberikan gambaran strategis peralatan produksi. (Puvanasvaran et al., 2013)

Menurut (Badiger et al., 2007). Studi literature mendukung bahwa OEE merupakan pengukuran perbaikan peralatan, tetapi terdapat jarak antara pendekatan sistematis dengan penerapan metode $O E E$. Tujuan penerapan metode $O E E$ pada perusahaan manufaktur, untuk menjaga perbaikan personel, dan peralatan perusahaan. Langkah-langkah penelitian ini ditunjukan dalam flow chart penelitian pada gambar 1 di bawah ini. 


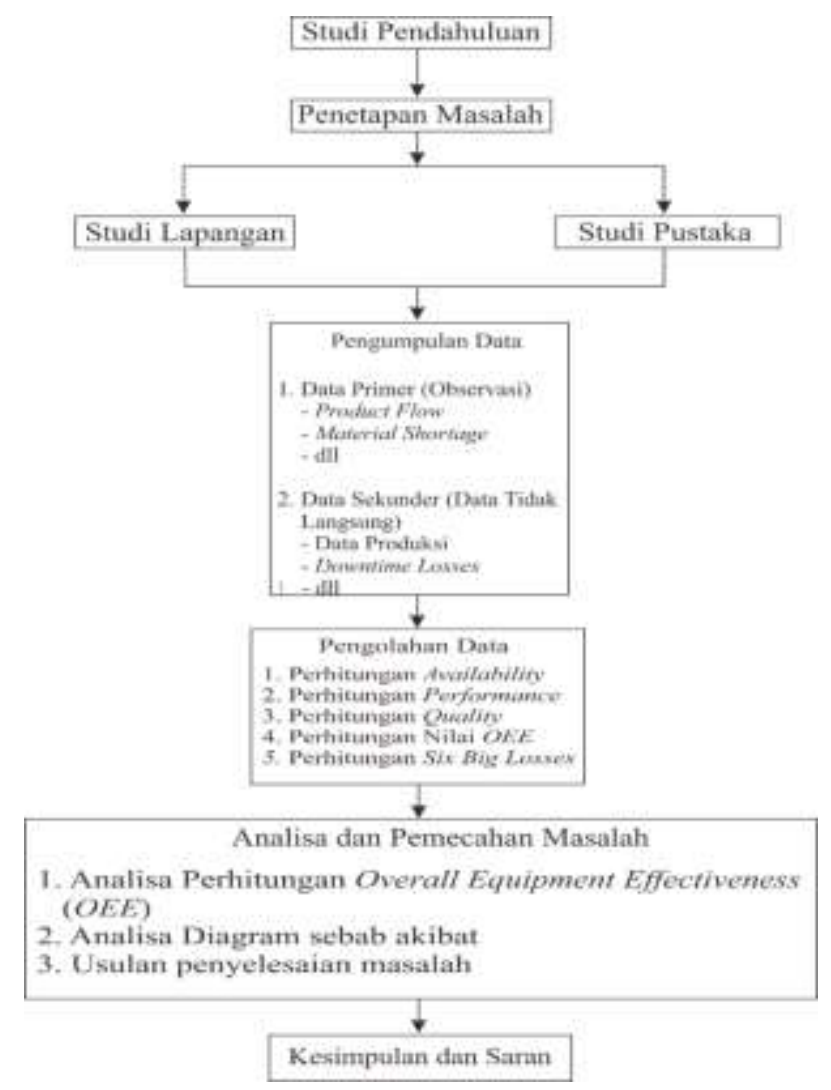

Gambar 1. Flow Chart Penelitian

\section{Hasil dan Pembahasan}

Availability ratio adalah merupakan rasio untuk menjelaskan waktu yang digunakan, dan waktu yang tersedia untuk aktivitas proses operasi mesin maupun peralatan. Berikut pada tabel 1 di bawah ini hasil pengukuran nilai availability ratio pada mesin Steel VMI tanggal 2 Januari 31 Januari 2020.

Tabel 1. Hasil Pengukuran Nilai Availability Ratio (Menit)

\begin{tabular}{cccccccc}
\hline Date & $\begin{array}{c}\text { Machine } \\
\text { Working } \\
\text { Times }\end{array}$ & $\begin{array}{c}\text { Planned } \\
\text { Downtime }\end{array}$ & $\begin{array}{c}\text { Loading } \\
\text { Time }\end{array}$ & $\begin{array}{c}\text { Equipment } \\
\text { Failure }\end{array}$ & Start Up & $\begin{array}{c}\text { Operation } \\
\text { Time }\end{array}$ & $\begin{array}{c}\text { Availability } \\
\text { Ratio } \\
(\%)\end{array}$ \\
\hline 2 & 1380 & 0 & 1380,0 & 0 & 0 & 1210,0 & $88 \%$ \\
3 & 1380 & 0,0 & 1380,0 & 0 & 0 & 1195 & $87 \%$ \\
4 & 1320 & 0,0 & 1320,0 & 20 & 0 & 1115 & $84 \%$ \\
5 & 1320 & 0,0 & 1320,0 & 130 & 0 & 1050 & $80 \%$ \\
6 & 1320 & 0,0 & 1320,0 & 0 & 0 & 1170 & $89 \%$ \\
7 & 1320 & 0,0 & 1320,0 & 0 & 0 & 1170 & $89 \%$ \\
8 & 1380 & 0,0 & 1380,0 & 60 & 0 & 1230 & $89 \%$ \\
9 & 1320 & 0,0 & 1320,0 & 0 & 0 & 1140 & $86 \%$ \\
10 & 1260 & 0,0 & 1260,0 & 0 & 0 & 1080 & $86 \%$ \\
11 & 1260 & 0,0 & 1260,0 & 25 & 0 & 1095 & $87 \%$ \\
12 & 1320 & 0,0 & 1320,0 & 0 & 0 & 1170 & $89 \%$ \\
13 & 1380 & 0,0 & 1380,0 & 0 & 0 & 1210 & $88 \%$
\end{tabular}




\begin{tabular}{|c|c|c|c|c|c|c|c|}
\hline Date & $\begin{array}{c}\text { Machine } \\
\text { Working } \\
\text { Times }\end{array}$ & $\begin{array}{c}\text { Planned } \\
\text { Downtime }\end{array}$ & $\begin{array}{l}\text { Loading } \\
\text { Time }\end{array}$ & $\begin{array}{l}\text { Equipment } \\
\text { Failure }\end{array}$ & Start Up & $\begin{array}{l}\text { Operation } \\
\text { Time }\end{array}$ & $\begin{array}{c}\text { Availability } \\
\text { Ratio } \\
(\%)\end{array}$ \\
\hline 14 & 1260 & 0,0 & 1260,0 & 0 & 0 & 1065 & $85 \%$ \\
\hline 15 & 1260 & 0,0 & 1260,0 & 0 & 0 & 1090 & $87 \%$ \\
\hline 16 & 1320 & 210,0 & 1110,0 & 95 & 0 & 845 & $76 \%$ \\
\hline 17 & 1260 & 0,0 & 1260,0 & 15 & 0 & 1100 & $87 \%$ \\
\hline 18 & 1260 & 0,0 & 1260,0 & 0 & 0 & 1080 & $86 \%$ \\
\hline 19 & 1260 & 0,0 & 1260,0 & 0 & 0 & 1120 & $89 \%$ \\
\hline 20 & 1260 & 0,0 & 1260,0 & 0 & 0 & 1085 & $86 \%$ \\
\hline 21 & 1320 & 0,0 & 1320,0 & 0 & 0 & 1075 & $81 \%$ \\
\hline 22 & 840 & 0,0 & 840,0 & 0 & 0 & 565 & $67 \%$ \\
\hline 23 & 1320 & 0,0 & 1320,0 & 0 & 0 & 1120 & $85 \%$ \\
\hline 24 & 1320 & 0,0 & 1320,0 & 30 & 0 & 1125 & $85 \%$ \\
\hline 25 & 1260 & 0,0 & 1260,0 & 30 & 0 & 1040 & $83 \%$ \\
\hline 26 & 1260 & 0,0 & 1260,0 & 25 & 0 & 985 & $78 \%$ \\
\hline 27 & 1260 & 0,0 & 1260,0 & 110 & 0 & 1000 & $79 \%$ \\
\hline 28 & 1260 & 0,0 & 1260,0 & 45 & 0 & 990 & $79 \%$ \\
\hline 29 & 1260 & 0,0 & 1260,0 & 20 & 0 & 1025 & $81 \%$ \\
\hline 30 & 1380 & 0,0 & 1380,0 & 60 & 0 & 1130 & $82 \%$ \\
\hline 31 & 1260 & 0,0 & 1260,0 & 60 & 0 & 970 & $77 \%$ \\
\hline Total & 38580 & 210,0 & 38370,0 & 725 & 0 & 32245,0 & \multirow{2}{*}{$84 \%$} \\
\hline Average & 1286 & 7,0 & 1279,0 & 24 & 0 & 1074,8 & \\
\hline
\end{tabular}

Performa Ratio, merupakan Rasio kinerja menunjukkan tingkat kegunaan mesin, atau peralatan untuk menghasilkan output. Berikut tabel 2 di bawah ini menunjukkan hasil pengukuran nilai performance ratio pada mesin Steel VMI tanggal 2 Januari - 31 Januari 2020:

Tabel 2. Hasil Pengukuran Nilai Performance Ratio (menit)

\begin{tabular}{cccccc}
\hline Date & $\begin{array}{c}\text { Operation } \\
\text { Time }\end{array}$ & $\begin{array}{c}\text { Actual } \\
\text { Production }\end{array}$ & $\begin{array}{c}\text { Cycle Time } \\
\text { Standard }\end{array}$ & $\begin{array}{c}\text { Actual } \\
\text { Cycle Time }\end{array}$ & $\begin{array}{c}\text { Performance } \\
\text { Ratio }(\%)\end{array}$ \\
\hline 2 & 1210,0 & 196 & 4,22 & 6,17 & $68 \%$ \\
3 & 1195,0 & 192 & 4,22 & 6,22 & $68 \%$ \\
4 & 1115,0 & 184 & 4,22 & 6,06 & $70 \%$ \\
5 & 1050,0 & 184 & 4,22 & 5,71 & $74 \%$ \\
6 & 1170,0 & 190 & 4,22 & 6,16 & $69 \%$ \\
7 & 1170,0 & 206 & 4,22 & 5,68 & $74 \%$ \\
8 & 1230,0 & 186 & 4,22 & 6,61 & $64 \%$ \\
9 & 1140,0 & 182 & 4,22 & 6,26 & $67 \%$ \\
10 & 1080,0 & 154 & 4,22 & 7,01 & $60 \%$ \\
11 & 1095,0 & 150 & 4,22 & 7,30 & $58 \%$ \\
12 & 1170,0 & 192 & 4,22 & 6,09 & $69 \%$ \\
13 & 1210,0 & 190 & 4,22 & 6,37 & $66 \%$ \\
14 & 1065,0 & 168 & 4,22 & 6,34 & $67 \%$ \\
15 & 1090,0 & 162 & 4,22 & 6,73 & $63 \%$ \\
16 & 845,0 & 96 & 4,22 & 8,80 & $48 \%$ \\
17 & 1100,0 & 137 & 4,22 & 8,03 & $53 \%$
\end{tabular}




\begin{tabular}{cccccc}
\hline Date & $\begin{array}{c}\text { Operation } \\
\text { Time }\end{array}$ & $\begin{array}{c}\text { Actual } \\
\text { Production }\end{array}$ & $\begin{array}{c}\text { Cycle Time } \\
\text { Standard }\end{array}$ & $\begin{array}{c}\text { Actual } \\
\text { Cycle Time }\end{array}$ & $\begin{array}{c}\text { Performance } \\
\text { Ratio }(\%)\end{array}$ \\
\hline 18 & 1080,0 & 152 & 4,22 & 7,11 & $59 \%$ \\
19 & 1120,0 & 162 & 4,22 & 6,91 & $61 \%$ \\
20 & 990,0 & 160 & 4,22 & 6,78 & $68 \%$ \\
21 & 1075,0 & 172 & 4,22 & 6,25 & $68 \%$ \\
22 & 565,0 & 160 & 4,22 & 3,53 & $120 \%$ \\
23 & 1120,0 & 142 & 4,22 & 7,89 & $54 \%$ \\
24 & 1125,0 & 156 & 4,22 & 7,21 & $59 \%$ \\
25 & 350,0 & 150 & 4,22 & 6,93 & $181 \%$ \\
26 & 985,0 & 176 & 4,22 & 5,60 & $75 \%$ \\
27 & 1000,0 & 151 & 4,22 & 6,62 & $64 \%$ \\
28 & 990,0 & 155 & 4,22 & 6,39 & $66 \%$ \\
29 & 1025,0 & 166 & 4,22 & 6,17 & $68 \%$ \\
30 & 970,0 & 182 & 4,22 & 6,21 & $79 \%$ \\
31 & 970,0 & 131 & 4,22 & 7,40 & $57 \%$ \\
\hline Total & 31300,0 & 4984 & 126,60 & 196,56 & $71 \%$ \\
Average & 1043,3 & 166 & 4,22 & 6,55 & \\
\hline
\end{tabular}

Quality Ratio, merupakan rasio merupakan kemampuan mesin dan pealatan dalam menghasilkan produk yang sesuai dengan standar. Berikut tabel 3 di bawah ini menunjukkan hasil pengukuran nilai quality ratio pada mesin Steel VMI tanggal 2 Januari - 31 Januari 2020:

Tabel 3. Hasil Pengukuran Nilai Quality Ratio (Menit)

\begin{tabular}{cccccccc}
\hline Date & $\begin{array}{c}\text { Value } \\
\text { Operating } \\
\text { Time }\end{array}$ & $\begin{array}{c}\text { Net Operating } \\
\text { Time }\end{array}$ & $\begin{array}{c}\text { Actual } \\
\text { Production }\end{array}$ & $\begin{array}{c}\text { Cycle Time } \\
\text { Standard }\end{array}$ & $\begin{array}{c}\text { Actual } \\
\text { Cycle Time }\end{array}$ & $\begin{array}{c}\text { Defect } \\
\text { loss }\end{array}$ & $\begin{array}{c}\text { Quality } \\
\text { Ratio } \\
(\%)\end{array}$ \\
\hline 2 & 827,12 & 827,12 & 196 & 4,22 & 6,17 & 0 & $100 \%$ \\
3 & 810,24 & 810,24 & 192 & 4,22 & 6,22 & 0 & $100 \%$ \\
4 & 776,48 & 776,48 & 184 & 4,22 & 6,06 & 0 & $100 \%$ \\
5 & 776,48 & 776,48 & 184 & 4,22 & 5,71 & 0 & $100 \%$ \\
6 & 801,80 & 801,80 & 190 & 4,22 & 6,16 & 0 & $100 \%$ \\
7 & 869,32 & 869,32 & 206 & 4,22 & 5,68 & 0 & $100 \%$ \\
8 & 784,92 & 784,92 & 186 & 4,22 & 6,61 & 0 & $100 \%$ \\
9 & 768,04 & 768,04 & 182 & 4,22 & 6,26 & 0 & $100 \%$ \\
10 & 649,88 & 649,88 & 154 & 4,22 & 7,01 & 0 & $100 \%$ \\
11 & 633,00 & 633,00 & 150 & 4,22 & 7,30 & 0 & $100 \%$ \\
12 & 810,24 & 810,24 & 192 & 4,22 & 6,09 & 0 & $100 \%$ \\
13 & 801,80 & 801,80 & 190 & 4,22 & 6,37 & 0 & $100 \%$ \\
14 & 708,96 & 708,96 & 168 & 4,22 & 6,34 & 0 & $100 \%$ \\
15 & 683,64 & 683,64 & 162 & 4,22 & 6,73 & 0 & $100 \%$ \\
16 & 405,12 & 405,12 & 96 & 4,22 & 8,80 & 0 & $100 \%$ \\
17 & 578,14 & 578,14 & 137 & 4,22 & 8,03 & 0 & $100 \%$ \\
18 & 641,44 & 641,44 & 152 & 4,22 & 7,11 & 0 & $100 \%$ \\
19 & 683,64 & 683,64 & 162 & 4,22 & 6,91 & 0 & $100 \%$ \\
20 & 675,20 & 675,20 & 160 & 4,22 & 6,78 & 0 & $100 \%$ \\
21 & 725,84 & 725,84 & 172 & 4,22 & 6,25 & 0 & $100 \%$ \\
& & & & & & 0 & 0 \\
\end{tabular}




\begin{tabular}{cccccccc}
\hline Date & $\begin{array}{c}\text { Value } \\
\text { Operating } \\
\text { Time }\end{array}$ & $\begin{array}{c}\text { Net Operating } \\
\text { Time }\end{array}$ & $\begin{array}{c}\text { Actual } \\
\text { Production }\end{array}$ & $\begin{array}{c}\text { Cycle Time } \\
\text { Standard }\end{array}$ & $\begin{array}{c}\text { Actual } \\
\text { Cycle Time }\end{array}$ & $\begin{array}{c}\text { Defect } \\
\text { loss }\end{array}$ & $\begin{array}{c}\text { Quality } \\
\text { Ratio } \\
(\%)\end{array}$ \\
\hline 22 & 675,20 & 675,20 & 160 & 4,22 & 3,53 & 0 & $100 \%$ \\
23 & 599,24 & 599,24 & 142 & 4,22 & 7,89 & 0 & $100 \%$ \\
24 & 658,32 & 658,32 & 156 & 4,22 & 7,21 & 0 & $100 \%$ \\
25 & 633,00 & 633,00 & 150 & 4,22 & 6,93 & 0 & $100 \%$ \\
26 & 742,72 & 742,72 & 176 & 4,22 & 5,60 & 0 & $100 \%$ \\
27 & 637,22 & 637,22 & 151 & 4,22 & 6,62 & 0 & $100 \%$ \\
28 & 654,10 & 654,10 & 155 & 4,22 & 6,39 & 0 & $100 \%$ \\
29 & 700,52 & 700,52 & 166 & 4,22 & 6,17 & 0 & $100 \%$ \\
30 & 768,04 & 768,04 & 182 & 4,22 & 6,21 & 0 & $100 \%$ \\
31 & 552,82 & 552,82 & 131 & 4,22 & 7,40 & 0 & $100 \%$ \\
\hline Total & 21032,5 & 21032,5 & 4984 & 126,60 & 196,56 & 0 & $100 \%$ \\
Average & 701,1 & 701,1 & 166,1 & 4,22 & 6,55 & 0 & \\
\hline
\end{tabular}

Dengan demikian, bahwa nilai Overall Equipment Effectiveness merupakan indeks atau ukuran yang menunjukan tingkat efektivitas mesin maupun peralatan dalam persentase. Setelah memperoleh nilai availability, performance, dan quality. Kemudian tabel 4 hasil pengukuran nilai OEE :

Tabel 4. Hasil Pengukuran Nilai $O E E$

\begin{tabular}{cccc}
\hline $\begin{array}{c}\text { Availability } \\
\text { Ratio }\end{array}$ & $\begin{array}{c}\text { Performance } \\
\text { Ratio }\end{array}$ & $\begin{array}{c}\text { Quality } \\
\text { Ratio }\end{array}$ & OEE \\
\hline $84 \%$ & $71 \%$ & $100 \%$ & $59 \%$ \\
\hline
\end{tabular}

Tabel 5. Hasil pengukuran Six Big Losses

\begin{tabular}{cccc}
\hline Six Big Losess & $\begin{array}{c}\text { Total Waktu } \\
\text { Kerugian }\end{array}$ & Persentase (\%) & Komulative (\%) \\
\hline Equipment Failure & 725 & $41.49 \%$ & $41.49 \%$ \\
Reduce Speed & 717 & $41.05 \%$ & $82.54 \%$ \\
Chokotei & 305 & $17.46 \%$ & $100 \%$ \\
Start Up & 0 & $0 \%$ & $100 \%$ \\
Deffect Loss & 0 & $0 \%$ & $100 \%$ \\
Scrap Loss & 0 & $0 \%$ & $100 \%$ \\
\hline Total & 1747 & $100 \%$ & - \\
\hline
\end{tabular}

Berdasarkan tabel 4 dan tabel 5 di atas bahwa nilai Six Big losses pada elemen OEE adalah equipment failure sebesar 725 menit atau $41.49 \%$, reduce speed sebesar 717 menit atau $41.05 \%$, dan chokotei sebesar 305 menit atau $17.46 \%$, yang memberikan beberapa penyebab menimbulkan rendahnya nilai OEE pada mesin Steel VMI. Dari 9 (sembilan) rata-rata losses lihat tabel 6 di bawah ini, yaitu, Star Up, change size, change material, material shortage, tool shortage, man hours losses, other losses, chokotei, dan quality problem.

Tabel 6. Rata-rata Kerugian waktu (losses time)

\begin{tabular}{ccccccccc}
\hline $\begin{array}{c}\text { Star Up } \\
(\text { min })\end{array}$ & $\begin{array}{c}\text { Change } \\
\text { Size } \\
(\text { min })\end{array}$ & $\begin{array}{c}\text { Change } \\
\text { Material } \\
(\text { min })\end{array}$ & $\begin{array}{c}\text { Material } \\
\text { Shortage } \\
(\text { min })\end{array}$ & $\begin{array}{c}\text { Tool } \\
\text { Shortage } \\
(\text { min })\end{array}$ & $\begin{array}{c}\text { Mours } \\
\text { Loss } \\
(\text { min })\end{array}$ & $\begin{array}{c}\text { Other } \\
\text { Loss } \\
(\text { min })\end{array}$ & $\begin{array}{c}\text { Chokotei } \\
(\text { min })\end{array}$ & $\begin{array}{c}\text { Quality } \\
\text { Problem } \\
\text { (min })\end{array}$ \\
\hline 0 & 69 & 71 & 0 & 40 & 0 & 0 & 10 & 39 \\
\hline
\end{tabular}


Tabel 7. Downtime Losses

\begin{tabular}{cccc}
\hline Variable & Time $(\mathrm{min})$ & Percent $(\%)$ & Cumulatif (\%) \\
\hline Change Material & 71 & $31.00 \%$ & $31 \%$ \\
Change Size & 69 & $30.13 \%$ & $61 \%$ \\
Tool Shortage & 40 & $17.47 \%$ & $78.5 \%$ \\
Quality problem & 39 & $17.03 \%$ & $95.8 \%$ \\
Chokotei & 10 & $4.37 \%$ & $100 \%$ \\
Material Shortage & 0 & $0 \%$ & $100 \%$ \\
Man Hours Loss & 0 & $0 \%$ & $100 \%$ \\
Star Up & 0 & $0 \%$ & $100 \%$ \\
Other Loss & 0 & $0 \%$ & $100 \%$ \\
\hline Total & 229 & $100 \%$ & - \\
\hline
\end{tabular}

Dari tabel 7 downtime losses di atas bahwa downtime losses keseluruhan terdapat nilai losses terbesar yaitu pada proses change material 71 menit atau 31\%, change size 69 menit atau 30.13\%, tool shortage 40 menit atau $17.47 \%$, quality problem 39 menit atau $17.03 \%$ dan chokotei 10 menit atau $4,37 \%$.

\section{Analisis Fish Bone}

Analisis fish bone yang dilakukan dengan gemba, dan wawancara secara langsung kepada karyawan (department), section head, foreman, helper, dan operator bahwa hasil gambaran diagram fish bone seperti man, machine, material, method, dan lingkungan kerja, lihat gambar 2 di bawah ini.

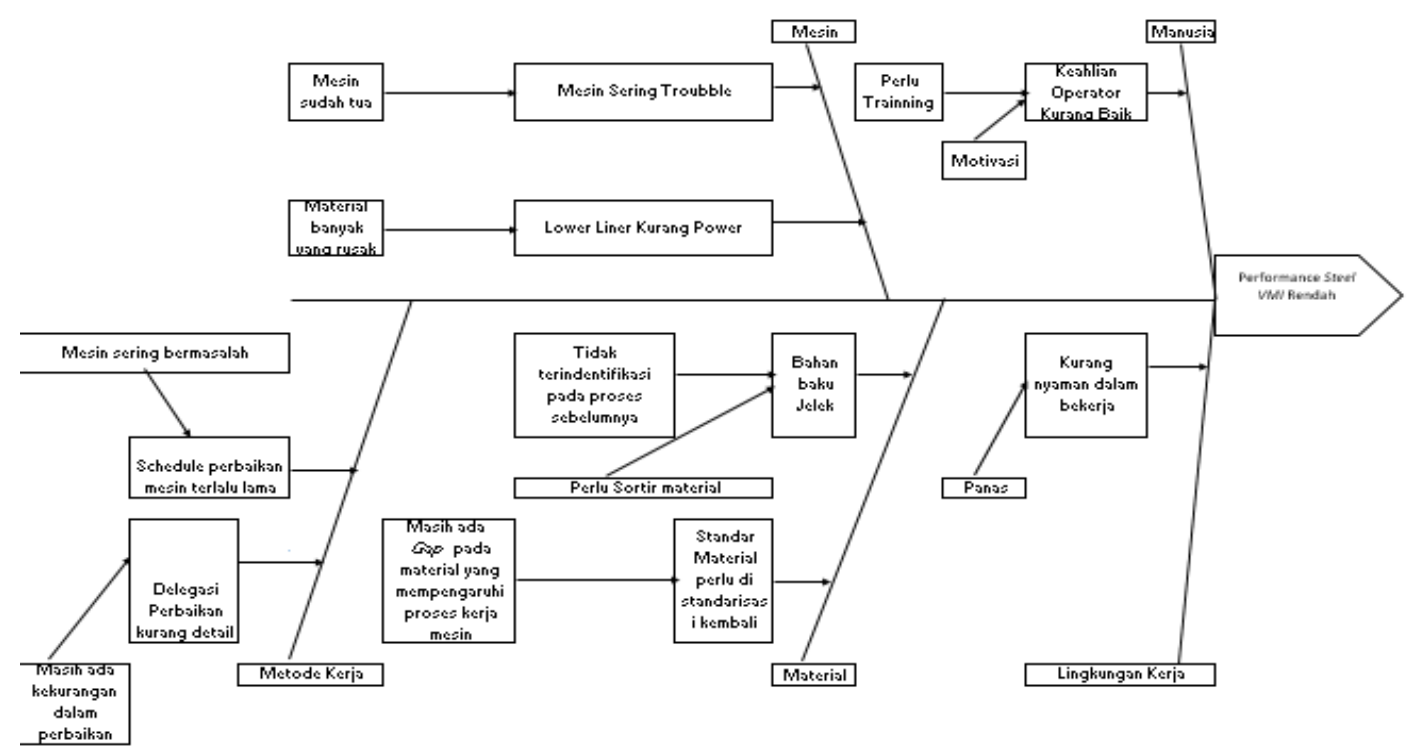

Gambar 2. Diagram Fishbone masalah mesin Steel VMI

\section{Usulan Tindakan Perbaikan}

Berdasarkan hasil penelitian yang dilakukan bahwa nilai OEE yang masih rendah tersebut, maka rencana usulan atau saran tindakan perbaikan, lihat tabel 8 di bawah ini. 
Tabel 8. Usulan Tindakan Perbaikan

\begin{tabular}{|c|c|}
\hline Permasalahan & Usulan Rencana Tindakan Perbaikan \\
\hline $\begin{array}{l}\text { Schedule Preventive Maintenance } \\
\text { terlalu lama }\end{array}$ & $\begin{array}{c}\text { Melakukan Preventive Maintenance setiap bulan } \\
\text { (disesuaikan dengan rencana perusahaan), melibatkan } \\
\text { operator dalam preventive maintenance sekaligus } \\
\text { membagikan pengetahuan dan keterampilan dari bagian } \\
\text { teknik terhadap operator produksi. }\end{array}$ \\
\hline $\begin{array}{l}\text { Loss time pada proses perbaikan } \\
\text { mesin kurang lengkap dan detil }\end{array}$ & $\begin{array}{l}\text { Ketika melakukan preventive maintenance diharapkan } \\
\text { secara menyeluruh, dengan seluruh kendala yang ada pada } \\
\text { mesin tersebut sehingga tidak terja di loss time. }\end{array}$ \\
\hline $\begin{array}{l}\text { Tidak tersedianya spare parts dan } \\
\text { material terlalu besar pada mesin }\end{array}$ & $\begin{array}{l}\text { Pembuatan material untuk membantu berjalannya mesin, } \\
\text { diharapkan tidak membuat sparepart over size. Sehingga } \\
\text { tidak terjadi gap pada salah satu bagian mesin, untuk }\end{array}$ \\
\hline Steel VMI & $\begin{array}{l}\text { mengurangi tingkat gesekan pada salah satu bagian mesin } \\
\text { ketika beroperasi }\end{array}$ \\
\hline $\begin{array}{c}\text { Kurangnya pengawasan dan human } \\
\text { error }\end{array}$ & $\begin{array}{l}\text { Perlu dilakukan pengawasan ketat dan periodik serta } \\
\text { person in charge (PIC) yang jelas }\end{array}$ \\
\hline
\end{tabular}

\section{Kesimpulan}

Dari hasil penelitian bahwa mesin Steel VMI memiliki nilai availability 84\%, nilai performance $71 \%$, dan nilai quality $100 \%$, maka hasil perhitungan nilai OEE nya sebesar $59 \%$. Dengan nilai OEE tersebut masih rendah di bawah nilai standar $O E E$ yaitu $85 \%$. Nilai rendahnya OEE tersebut bahwa disebabkan oleh losses terbesar dari equipment failure losses sebesar $41.49 \%$, reduce speed losses sebesar $41.05 \%$ dan chokoteil idling minor stoppage yaitu sebesar $17,46 \%$.

Penyebab rendahnya nilai $O E E$ dan losses time disebabkan oleh schedule preventive maintenance terlalu lama, loss time pada proses perbaikan mesin kurang lengkap dan detil, dan Tidak tersedianya spare parts dan material terlalu besar pada mesin Steel VMI dan kurangnya pengawasan dan human error.

\section{Daftar Pustaka}

Badiger, A. S., Gandhinathan, R., Giatonde, V. N., \& Jangaler, R. S. (2007). Implementation of Kaizen and Poka-yoke to Enhance Overall Equipment Performance - A case study. Manufacturing Engineering.

Puvanasvaran, P., Teoh, Y. S., \& Tay, C. C. (2013). Consideration of demand rate in Overall Equipment Effectiveness (OEE) on equipment with constant process time. Journal of Industrial Engineering and Management, 6(2), 507-524. https://doi.org/10.3926/jiem.537

S.Nakajima. (1988). Introduction to TPM: Total Productive Maintenance.pdf. Productivity Press, Cambridge. https://doi.org/http://www.plantmaintenance.com/articles/tpm_intro.shtml

Saiful, S., Rapi, A., \& Novawanda, O. (2014). PENGUKURAN KINERJA MESIN DEFEKATOR I DENGAN MENGGUNAKAN METODE OVERALL EQUIPMENT EFFECTIVENESS(Studi Kasus pada PT. Perkebunan XY ). Journal of Engineering and Management Industial System. https://doi.org/10.21776/ub.jemis.2014.002.02.2

Sukanta, Burhan, N., \& Sari, D. A. (2019). Analysis of Overall Equipment Effectiveness in Fanuc Line 1 Machines by Minimizing six big losses. Journal of Sustainable Engineering: Proceedings Series 1(2) 2019, 1(IConSEP), 164-173. https://doi.org/10.35793/joseps.v1i2.22

Sukanta, S., Maulana, R., \& Sari, D. A. (2019). Implementations of Autonomous Maintenance to Relieve Stoppages on PT NIKF - Sachet Packaging Chain. IPTEK The Journal for Technology and Science, 29(3), 65. https://doi.org/10.12962/j20882033.v29i2.3569

Triwardani, D., Rahman, A., \& Tantrika, C. (2012). Analisis Overall Equipment Effectiveness (OEE) dalam Meminimalisi Six Big Losses Pada Mesin Produksi Dual Filters DD07 (studi 
kasus : PT. Filtrona Indonesia, Surabaya, Jawa Timur. Jurusan Teknik Industri Universitas Brawijaya, 07, 379-391.

Ir. Kurniawan F, M.Si., RQP, (2013). Dalam buku Manajemen Perawatan Industri.

Edisi Pertama, Yogyakarta: Graha Ilmu.

Dokumen perusahaan, (2020). Tire Manufacturing Process.

Sejarah Perusahaan. [online]. https://www.xyz.co.id/company-profile/ (Diakses Januari 2020).

Laporan perusahaan. Corporate Annual Report. 
[ Halaman kosong ] 